THe annual general meeting of the Royal Horticultural Society of Ireland was held in Dublin on the gth of November. The report of the Council was most satisfactory, and the treasurer's account showed a balance on the year to the credit of the society of upwards of $1,060 \%$. Of this sum 1,000l. was added to the reserve find. In addition to the usual early Spring, Summer, and Antumn shows it was resolved to hold in October next a grand international fruit show, which we hope will be attended with success.

MR. Jorin RUSirin has lately presented a valuable collection of minevals and fossils to the High School, Nottingham. Among the former are two hundred metalliferous ores, including some rare specimens from Hungary, a hundred choice silicates, the principal varieties of fluor spar, calcite, arid barytes, some agates, and a series of fine geins. The fossils are mainly from the Cretaceous Rocks of Kent and Sussex.

ON Saturday last Sir William Stirling Maxwell was elected Rector of the University of Edinburgh.

THE great Aquarium at the Crystal Palace, of which we recently gave a full description and drawing, was formally opened to the public on Friday evening last by a soirte.

THE Sersion of the Institution of Civil Engineers conmenced on the I 4 th inst., and the ammul general meeting "to raceive and deliberate upon the report of the Council on the state of the Institulion, and to elect the officers for the ensuing year," will be held on Tuesday, the Igth of December. At the same time the rnembers have been reminded of the obligation entered into on clection to promote the public and scientific obligations contemplated in the Royal Charter of Incorporation granted to the institution by preparing, or aiding in the preparation of, original communications for reading at the meetings, by frequent attendance $a$ t the meetings and occasionally taking part in the discussion, and by presenting to the library copies of reports and scientific treatises not already in the collection. It has also been notified that the qualifications of candidates seeking admission into the institution must in all cases be set forth with the utmost precision and in considerable detail, in order to enable the Council, upon whom the classification involves, and the members, with whom the subsequent election rests, to form a correct opinion as to the nature of the practice, the extent of the experience, and the degree of responsibility of every candidate. The casualties which have occurred among the members of this body during the last three months include the death of Field-Marshal Sir John Burgoyne, G.C.B., \&c., honorary member; of Messrs. Joseph Hamilton Beattie, John George Blackburne, Robert Benson Dockray, Albinus Martin, and Josiah Parkes, members ; and of Messiss. Arthur Field, Edward Mosely Perkins, and Henry Beadon Rotton, associates. This has reduced the total number of members of all classes from 2,009, at which it stood on the xst of August last, to 2,000 , comprising 14 honorary members, 725 members, 1,056 associates, and 205 students. During the period referred to the ordinary general meetings have been suspended, so that there has been no ballot for new mernbers.

Mr. Brothers has made a photograph eight inches in diameter of one of Mr. Proctor's star maps, containing nearly fifty thousand stars. The more marked constellations are just distinguishable upon a background, which appears to be shaded with innimerable minute points representing smaller stars. The increase of intensity in the shading is very evident upon certain parts of the picture. The whole represents the heavens as we should see them if the pupils of our eyes were a little more than two inches in diameter.

Dr. J. B. PETTIGREW, F.R.S., will deliver a course of twelve lectures on physiological and pathological subjects at the Royal College of Surgeons, Edinburgh.

\section{THE GEOGNOSY OF THE APPALACHIANS AND THE ORIGIN OF CRYSTALLINE ROCKS *}

III.

THF, direct formation of the crystalline schists from an aqueous magma is a notion which belongs to an early period in geological theory. De la Beche, in $1834, t$ conceived that they were thrown down as chemical deposits from the waters of the heated ocean, after its reaction on the crust of the cooling globe, and before the appearance of organic life. This view was revived by Daubrée in 1860 . Having sought to explain the alteration of paleoozoic strata of mechanical origin, by the action of heated waters, he proceeds to discuss the origin of the still more ancient crystalline schists. The first precipitated waters, according to him, acting on the anhydrous silicates of the earth's crust, at a very elevated temperature, and at a great pressure, which he estimated at two hundred and fifty atmospheres, formed a magma, from which, as it cooled, were successively deposited the various strata of the crystalline schists.+ This hypothesis, violating, as it does, all the notions which sound theory teaches with regard to the chemistry of a cooling globe, has, moreover, to encounter grave geognostical difficulties. The pre-Silurian crystalline rocks belong to two or more distinct systems of different ages, succeeding each other in discordant stratification. The whole history of these rocks, moreover; shows that their various alternating strata were deposited, not as precipitates fronz a seething solution, but under conditions of sedimentation very like those of more recent times. In the oldest known of them, the Laurentian system, great limestone formations are interstratifed with gneisses, quartzites, and even with conglomerates. All analogy, moreover, leads us to conclude that even at this early period life existed at the surface of the planet. Great accumulations of iron-oxyd, beds of metallic sulphids, and of graphite, exist in these oldest strata, and we know of no other agency than that of organic matter capable of generating these products.

Bischof had already arrived at the conclusion, which in the present state of our knowledge seems inevitable, that "all the carbon yet known to occur in a free state can only be regarded as a product of the decomposition of carbonic acid, and as derived from the vegetable kingdom." He further adds, "living plants decompose carbonic acid; dead organic matters decompose sulphates, so that, like carbon, sulphur appears to owe its existence in a free state to the organic kingdom." "s As a decomposition (deoxidation) of sulphates is necessary to the production of metallic sulphids, the presence of the latter, not less than that of free sulphur and free carbon, depends on organic bodies; the part which these play in reducing and rendering soluble the peroxyd of iron, and in the production of iron ores, is, moreover, well lnown. It was, therefore, that, after a careful study of these ancient rocks, I declared in May, I858, that a great mass of evidence " points to the existence of organic life, even during the Laurentian or soncalled azoic period." li

This prediction was soon verified in the discovery of the Eo. zoön Canadense of Dawson, the organic character of which is now admitted by all zoologists and geologists of authority. But with this discovery appeared another fact, which afforded a signal verification of my theory as to the origin and mode of deposition of serpentine and pyroxene. The microscopic and chemical researches of Dawson and myself showed that the calcareous skel. eton of this foraminiferal organism was filled with the one or the other of these" silicates in such a manner as to make it evident that they had replaced the sarcode of the animal, precisely as glauconite and similar silicates have, from the Silurian times to the present, filled and injected more recent foraminiferal skeletons. I recalled, in connection with this discovery, the observations of Ehrenberg, Mantell, and Bailey, and the more recent ones of Pourtales, to the effect that glauconite or some similar substance occasionally fills the spines of Echini, the cavities of corals and millepores, the canals in the shells of Balanus, and even forms casts of the holes made by burrowing sponges (Clionia) and * Address of Prof. $T$. Sterry Hunt on retiring from the office of President
of the American Association for the Advancement of Science ; abridged

$f$ from the "American Naturalist," concluded from p. 34.
$\ddagger$ Researches in Theoretical Geology, pp. 297-300.

Etudes et expériences synthétiques sux le Metamorphisme, pp. irg-izr.

Bischof, Lehrbuch, xst ed. II. 95. F.nglish ed. I, 252, 344.

1 Amer. Jour. Science, II. xxy. 436 . 
worms. The significance of these facts was further illustrated by showing that the so-called glauconites differ considerably in composition, some of them containing more or less alumina or magnesia, and one from the tertiary limestones near Paris being, accorting to Berthier, a true serpentine. *

These facts in the history of Eozoön were first made known by me in May 1864, in the American . Fournal of Science, and subsequently more in detail, February 1865 , in a communication to the Geological Society of London. $*$ They were speedily verified by $D$ r. Giimbel, who was then engaged in the study of the ancient crystalline schists of Bavaria, and who soon recognised the existence, in the limestones of the old Hercynian gneiss, of the characteristic Eozoön Canadense, injected with silicates in a manner precisely similar to that observed by Dawson and myself.; Later, in 1869 , Robert Hoffmann described the results of a minute chenrical examination of the Eozoön from Raspenau, in Bohernia, confirming the previous observations in Canada and Bavaria. He showed that the calcareous shell of the Eozoön examined by him, had been injected by a peculiar silicate, which may be described as related in composition both to glauconite and to chlorite. The masses of Eozoon he found to be enclosed and wrapped around by thin alternating layers of a green magnesian silicate allied to picrosmine, and a brown non-magnesian mineral, which proved to be a hydrous silicate of alumina, ferrous oxyd, and alkalies, related in composition to fahlunite, or more nearly to jollyte. \&

Still more recently, in the course of the present year, Dr. Daw* son detected a mineral insoluble in acids, injecting the pores of crinoidal stems and plates in a palrozoic limestone from New Brunswick, which is made up of organic remains. This silicate which, in decalcified specimens, shows in a beautiful manner the intinate structure of these ancient crinoids, I have found by analysis to be a hydrons silicate of alumina and ferrous oxyd, with magnesia and alkalies, closely reiated to fahlunite and to jollyte.ll The microscopic examinations of Dr. Dawson show that this silicatc injected the pores of the crinoidal remains and some of the interstices of the associated shell-fragments, before the introduction of the calcite which cements the mass. I have since found a silieate almost identical with this, occurring under similar conditions ia an Upper Silurian limestone said to be from Llangedoc in Wiales.

Giimbel, meanwhile, in the essay on the Laurentian rocks of Bavaria, in 1866 , already referred to, fully recognised the truth of the views which I had put forward, both with regard to the mineralogy of Eozoön and to the origin of the crystalline schists. I is results are still farther detailed in his Goognost. Beschreibung des ëstbayerischen Grenzegebirges, 1868, p. 833. Credner, moreover, $2 s$ he tells us, , Thad already from his mineralogical and Iithological studies, been led to admit my views as to the original formation of serpentine, pyroxene, and similar silicates (which he cites from my paper of 1865 , above referred to**), when he found that Gimbel had arrived at similar conclusions: The views of the latter, as cited by Credner from the work just referred to, are in substance as follows:- - The crystalline schists, with their interstratified layers, have all the characters of altered sedimentary deposits, and from their mode of occurrence cannot be of igneous origin, nor the result of epigenic action. The originally formed sediments are conceived to have been amorphous, and under moderate heat and pressure to have arranged themsclves, and crystallised, generating various mineral species in their midst by a change, which, to distinguish it from metamorphism by an epigenic process, Giimbel happily designates diagenesis.

It is unnecessary to remark that these views, the conclusions from the recent studies of Guimbel in Germany and Credner in North America, are identical with those put forth by me in 1860 .

At the early periods in which the materials of the ancient crystalline schists were accumulated, it cannot be doubted that the chemical processes which generated silicates were much more active than in more recent times. The heat of the earth's crust was probably then far greater than at present, while a high temperature prevailed at comparatively small depths, and thermal waters abounded. A denser atmosphere, charged with carbonic acid gas, must also have contributed to maintain, at the earth's

* Amer. Jour. Sci. II. xl. 360, Report Geol. Survey Canada, 1866, p. 23I, and Quar. Geol. Jour. XXI. $7^{\mathrm{x}}$

† Amer. Jour. Sci. II. xxxvii. 43x. Quar. Geol. Jour. XXI. 67

\pm Proc. R. Bavar. Acad. for 3866 , and Canadian Naturalist, N. S., III. $8 x$

$\$$ Jour. für Prakt. Chem. May, r869, and Amer. Jour. Sci. IIII. i. $37^{8}$

Amer. Jour. Sci. III. i. 379.

If Hermann Credner; die Gleiderung der Eozoischen Formationsgruppe Nord Amerikas. Halle, I869.

** That in the Quar, Geol. Jour, XXI. 67. surface, a greater degree of heat, though one not incompatible with the existence of organic life. " These conditions must have favoured many chemical processes, which, in later times, have nearly ceased to operate. Hence we find that subsequently to the eozoic times, silicated rocks of clearly marked chemical origin are comparatively rare. In the mechanical sediments of later periods certain crystalline minerals may be developed by a process of molecular re-arrangementdiagenesis. These are, in the feldspathic and aluminous sediments, orthoclase, muscovite, garnet, staurolite, cyanite, and chiastolite, and in the more basic sediments, hornblendic minerals. It is possible that these latter and similar silicates may sometimes be generated by reactions between silica on the one hand and carbonates and oxyds on the other, as already pointed out in some cases of local alteration. Such a case may apply to more or less hornblendic gneisses, for example; but no sediments, not of direct chemical origin, are pure enough to have given rise to the great beds of serpentine, pyroxene, steatite, labradorite, \&c., which abound in the ancient crystalline schists. 'Thus, while the materials for producing, by diagenesis, the aluminous silicates just mentioned, are to be met with in the mud and clay. rociss of all ages, the chemically formed silicates capable of crystallising into pyroxene, talc, serpentine, \&c., have only been formed under special conditions.

The same reasoning which led me to maintain the theory of an original formation of the mineral silicates of the crystalline schists, induced me to question the received notion of the epigenic origin of gypsums and magnesian limestones or dolomites. The interstratification of dolomites and pure limestones, and the enclosure of pebbles of the latter in a paste of crystalline dolomite, are of themselves sufficient to show that in these cases, at least, dolomites have not been formed by the alteration of pure limestones. The first results of a very long series of experiments and inquiries into the history of gypsum were published by me in I859, and further researches, reiterating and confirming my previous conclusions, appeared in I866. In these two papers it will, I thirklk, be found that the following facts in the listory of dolomite are established, viz. : first, its origin in nature by direct sedimentation, and not by the alteration of non-magnesian limestones; second, its artificial production by the direct union of carbonate of lime and hydrous carbonate of magnesia, at a gentle heat, in the presence of water. As to the sources of the hydrous magnesian carbonate, I have endeavoured to show that it is formed from the magnesian chlorid or sulphate of the sea or other saline wraters in two ways:-first, by the action of the bicarbonate of soda found in many natural waters; this, after converting all soluble lime-salts into insoluble carbonate, forms a comparatively soluble bicarbonate of magnesia, from which a hydrous carbonate slowly separates; secondly, by the action of bicarbonate of lime in solution, which, with sulphate of magnesia, gives rise to gypsum ; this first crystallises out, leaving behind a much more soluble bicarbonate of magnesia, which deposits the hydrous carbonate in its turn. In this way for the first time, in 1859, the origin of gypsums and their intimate relation with magnesian limestones were explained.

It was, moreover, shown that to the perfect operation of this reaction, an excess of carbonic acid in the solution, cluring the evaporation, was necessary to prevent the decomposing action of the hydrous mono-carbonate of magnesia upon the already formed gypsum. Having found that a prolonged exposure to. the air, by permitting the loss of carbonic acid, partially interfered with the process, I was led to repeat the experiment in a confined atmosphere, charged with carbonic acid, but rendered drying by the presence of a layer of dessicated chlorid of calcium. As had been foreseen, the process under these conditions proceeded uninterruptedly, pure gypsum first crystallising out from the liquid, and subsequently the hydrous magnesian carbonate. This experiment is instructive as showing the results which must have attended this process in past ages, when the quantity of carbonic acid in the atmosphere greatly exceeded its present amount.

As regards the hypotheses put forward to explain the supposed dolomitisation of previously-formed limestones by an epigenic process, I may remark that I repeated ver'y many times, under varying conditions, the often-cited experiment of Von Morlot, who claimed to have generated dolomite by the action of sulphate of magnesia on carbonate of lime, in the presence of water at a

* Amer. Jour. Sci. II. xxxvi. 396.

$\dagger$ Amer. Jour. Sci. MI xxxviii. 170, 365 ; xlii. 49 . \$ Proceedings Roya
New Series, III. 23I. 
somewhat elevated temperature under pressure. I showed that what he regarded as dolomite was not such, but an admixture of carbonate of lime with anhydrous and sparingly soluble carbonate of magnesia ; the conditions in which the carbonate of magnesia is liberated in this reaction not being favourable to its union with the carbonate of lime to form the double salt which constitutes dolomite. The experiment of Marignac, who thought to form dolomite by substituting a solution of chlorid of magnesium for the sulphate, I found to yield similar results, the greater part of the magnesian carbonate produced passing at once into the insoluble condition, without combining with the excess of carbonate of lime present. The process for the production of the double carbonate described by $\mathrm{Ch}$. Deville, namely, the action of vapours of anhydrous magnesian chlorid on heated carbonate of lime, in accordance with Von Buch's strange theory of dolomitisation, I have not thought necessary to submit to the test of experiment, since the conditions required are scarcely conceivable in nature. Multiplied geognostical observations show that the notion of the epigenic production of dolomite from limestone is untenable, although its resolution and deposition in veins, cavities, or pores in other rocks is a phenomenon of frequent occurrence.

The dolomites or magnesian limestones may be conveniently considered in two classes; first, those which are found with gypsums at various geological horizons ; and secondly, the more abundant and widely distributed rocks of the same kind, which are not associated with deposits of gypsum. The production of the first class is dependent npon the decomposition of sulphate of magnesia by solutions of bicarbonate of lime, while those of the second class owe their origin to the decomposition of magnesian chlorid or sulphate by solutions of alkaline bicarbonates. In both cases, however, the bicarbonate of magnesia, which the carbonated waters generally contain, contributes a more or less important part to the generation of the magnesian sediments. The carbonated alkaline waters of deep-seated springs often contain, as is well known, besides the bicarbonates of soda, lime and magnesia, compounds of iron, manganese, and many of the rarer metals in solution, and thus the metalliferous character of many of the dolomites of the second class is explained. The simultaneous occurrence of alkaline silicates in such mineral waters, would give rise, as already pointed out, to the production of insoluble silicates of magnesia, and thus the frequent association of such silicates with dolomites and magnesian carbonates in the crystalline schists is explained, as marking portions of one continuous process. The formation of these mineral waters depends upon the decomposition of feldspathic rocks by subterranean or sub-aërial processes, which were doubtless more active in former ages than in our own. The subsequent action upon magnesian waters of these bicarbonated solutions, whether alkaline or not, is dependent upon climatic conditions, since, in a region where the rainfall is abundant, such waters would find their way down the river-courses to the open sea, where the excess of dissolved sulphate of lime would prevent the deposition of magnesian carbonate. It is in dry and desert regions, with limited lake-basins, that we must seek for the production of magnesian carbonates, and I have argued from these considerations that much of northeastern America, including the present basins of the Upper Mississippi and St. Lawrence, must, during long intervals, in the palæozoic period, have had a climate of excessive dryness, and a surface marked by shallow enclosed basins, as is shown by the widely-spread magnesian limestones, and the existence of gypsum and rock-salt at more than one geological horizon within that area. * The occurrence of serpentine and diallage at Syracuse, New York, offers a curious example of the local development of crystalline magnesian silicates in Upper Silurian dolomitic strata under conditions which are imperfectly known, and which, in the present state of the locality, cannot be studied. $\uparrow$

Since the uncombined and hydrated magnesia mono-carbonate is at once decomposed by sulpbate or chlorid of calcium, it follows that the whole of these lime-salts in a sea-basin must be converted into carbonates before the production of carbonated magnesian sediments can begin. The carbonate of lime formed by the action of carbonates of magnesia and soda, remains at first dissolved as bicarbonate, and is only separated in a solid form, when, in excess, or when required for the needs of living plants or animals, which are dependent for their supply of calcareous matter, on the bicarbonate of lime produced, in part by the process just described, and in part by the action of car-

* Geology of South-western Ontario, Amer. Jour. Sci. II. xlvi. 355

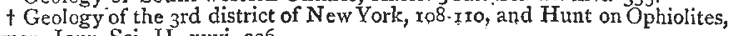
Amer. Jour. Sci, II. xxyi. $23^{6}$. bonic acid on insoluble lime-compounds of the earth's solid crust So many limestones are made up of calcareous organic remains, that a nution exists among many writers on geology that all limestones are, in some way, of organic origin. At the bottom of this lies the idea of an analogy between the chemical relations of vegetable and animal life. As plants give rise to beds of coal, so animals are supposed to produce limestones. In fact, how. ever, the synthetic process by which the growing plant, from the elements of water, carbonic acid and ammonia, generates hydrocarbonaceous and azotised matters, has no analogy with the assimilative process by which the growing animal appropriates alike these organic matters and the carbonate and phosphate of lime. Without the plant, the synthesis of the hydrocarbons would not take place, while independently of the existence of coral or mollusk, the carbonate of lime would still be generated by chemical reactions, and would accumulate in the waters until, these being saturated, its excess would be deposited as gypsum or rock-salt are deposited. Hence, in such waters, where, from any causes, life is excluded, accumulations of pure carbonate of lime may be formed. In I86I I called attention to the white marbles of Vermont, which occur intercalated among impure and fossiliferous beds, as apparently examples of such a process. *

It is by a fallacy similar to that which prevails as to the organic origin of limestones, that Daubeny and Murchison were led to appeal to the absence of phosphates from certain old strata as evidence of the absence of organic life at the time of their accumulation. $\uparrow$ Phosphates, like silica and iron-oxyd, were doubtless constituents of the primitive earth's crust, and the production of apatite crystals in granitic veins, or in crystalline schists, is a process as independent of life as the formation of crystals of quartz or of hematite. Growing plants, it is true, take up from the soil or the waters dissolved phosphates, which passed into the skeletons of animals, a process which has been active from very remote periods. I showed in 1854 that the shells of Lingula and Orbicula, both those from the base of the palrozoic rocks and those of the present time have (like Conularia and Serpulites) a chemical composition similar to the skeletons of vertebrate animals. $*$ The relations of both carbonate and phosphate of lime to organised beings are similar to those of silica, which, like them, is held in watery solution, and by processes independent of life is deposited both in amorphous and crystalline forms, but in certain cases is appropriated by diatoms and sponges, and made to assume organised shapes. In a word, the assimilation of silica, like that of phosphate and carbonate of lime, is a purely secondary and accidental process, and where life is absent, all of these substances are deposited in mineral and inorganic forms.

I have thus endeavoured to sketch, in a concise and rapid manner, the history of the earlier rock-formations of eastern North America, and of our progress in the knowledge of them; while $I$ have, at the same time, dwelt upon some of the geognos. tical and chemical questions which their study suggests. With the record of the last thirty years before them, American geologists have cause for congratulation that their investigations have been so fruitful in yreat results. They see, however, at the same time, how much yet remains to be done in the study of the Appalachians and of our north eastern coast, before the history of these ancient rock-formations can be satisfactorily written. Meanwhile our adventurous students are directing their labours to the vast regions of western America, where the results which have already been obtained are of profound interest. The progress of these investigations will doubtless lead us to modify many of the views now accepted in science, and cannot fail greatly to enlarge the bound of geological knowledge.

\section{THE SCOTTISH SCHOOL OF GEOLOGY $\$$} II.

WHILE Hutton fortified his convictions by constant appeals to the rocks themselves, his disciple Hall tested their truth in the laboratory. It is the boast of Scotland to have led the way in the application of chemical and physical experiment to the elucidation of geological history. It was objected to Hutton's theory, that if basalt and similar rocks had ever been is a

* Amer. Jour. Sci. II. xxxi. 492

+ Siluria, 4th ed. pp. 28 and 537

\$ A Lecture delivered at the opening of the class of Geology and Mineralogy in the University of Edinburgh, by Archibald Geikie, F.R.S., Nov, 6, 187 I,
concluded from P. 39 . 